\title{
Agriculture Education for Rural Development in Nepal
}

\author{
Dr. Phanindra Kumar Chaudhary* and Rajan Binayek Pasa \\ *Programme Director \\ Community Development Programme, Training and Education Department \\ Training Institute for Technical Instruction (TITI) \\ Sanothimi, Bhaktapur, Nepal \\ Email for correspondence: pkc@titi.org.np or pkctharu@yahoo.com
}

\begin{abstract}
This paper appraises the possible importance of accessible agriculture education program in agriculture and rural development sectors. Rural development is a strategy for reducing poverty and uplift socio-economic infrastructures in rural areas especially through agriculture development which is almost impossible without proper management of agriculture graduates and trained farmers. An attempt is also made to examine the transformative role of responsible public and private mechanism, skilled farmers and agriculture graduates for achieving ultimate goals and objectives of agricultural policies and rural development efforts during various plan periods. However, still most of agriculture graduates have to be encouraged to working with farmers and need to be devoted in agricultural based occupations. Nepalese economy has undergone a gradual structural shift in the recent years and there is $4.03 \%$ average GDP contribution by agriculture sector. Still 2.5 million people need immediate assistance because of insufficient land and production and 4.4 million people are trapping in food insecurity because of raising price in food grains. But Nepal ranked as the sixth largest producer of lentils and the third largest producers of ginger. Cardamom, lentils, tea and ginger are also the leading agricultural export items. This situation suggests that the country is still potential destination form the perspectives commercial farming and agricultural transformation, if the government gives excessive emphasize to providing accessible and affordable agriculture education opportunities to socio-economically backward students whose family members are still working in agriculture sectors. This paper emphasizes that formulating agriculture and rural development policies are not proper way to solve socio-economic problems but it is inevitable to diffuse agriculture education program in rural areas for producing skilled and knowledgeable workforce. The government needs to expand agricultural service delivery mechanism and mobilize agriculture graduates in remote areas and private sectors also need to invest in agriculture sectors as for struggling against food insecurity.
\end{abstract}

Key words: Agriculture education, agricultural development, rural development

\section{Introduction}

Rural development (RD) is overall development of rural areas with view to improve the quality of life of rural people. It is comprehensive and multidimensnal concept and 
encompasses the development of agriculture and allied activities, village industries and crafts socio-economic infrastructures in rural areas (Singh, 1999, p.20). Conceptually, $\mathrm{RD}$ is a development strategy that can be designed to improve the socio-economic life of rural poor; as such it involves extending the benefits of development to the poorest in rural areas e.g. small farmers, tenants, landless and other disadvantage groups (World Bank, 1975).Theoretically, rural development seeks to alleviate poverty, mass utilization of resources, commercialization of agriculture, food security, creating opportunities, infrastructural development of rural community and modernization of overall society.

In this consideration, agriculture development is a major foundation of RD where agriculture's share in GDP is estimated to be about one third or 33.9 percent (Central Bureau of Statistics, 2014). It can be said that the success of overall development is an outcome of what happens in agriculture (Addison, 2005). Owing to agricultural issue, 83 percent of total population $(26,494,504)$ is still living in rural areas whose primary occupation is agriculture (CBS, 2011). Agriculture sector also has been providing employment opportunities to local people where category of self-employment in agriculture is 61.3 percent and wage employment in agriculture is 2.1 percent (NLSS, 2011). Therefore, in my opinion process of rural development at least should be more concerned on agriculture education that can produce skilled and technical human resources for agriculture development instead of physical and social infrastructures. In this regard, the paper tries to unpack importance of agriculture education for rural development so that continuous efforts on rural development can be addressed.

Historically, school of agriculture was established under the Ministry of Agriculture in 1957. The school was set up to produce lower-level technical manpower to serve farmers called 'Junior Technical Assistants (JTA)'. Later, in 1968, the school was upgraded to the College of Agriculture and a two-year 'Intermediate of Agriculture Science (ISc.Ag)' program was started, producing middle level technical manpower in agriculture, known as Junior Technicians (JT). In 1972, the college was upgraded to the 'Institute of Agriculture and Animal Sciences (IAAS)' under the umbrella of Tribhuvan University and relocated from Kathmandu to Rampur in Chitwan district with an area of 110 hectares. Again in July 1972, the institute was brought under TU and renamed as the 'Institute of Forestry (IOF).

In response to the growing demand for agriculture technicians and graduates in the country, several private and governmental colleges were established at the start of 20th century. The Himalayan College of Agriculture Sciences and Technology (HICAST) was established in 2000 at Bhaktapur and offered Bachelor and Master's level courses on agriculture and veterinary sciences. Similarly, Gokuleshwor Campus under IAAS was established in the western part of the country in 2010. Realizing the importance of trained human resources in agriculture and forestry sector, the cabinet decided to establish a new 'Agriculture and Forestry University (AFU)' in 2010. Similarly, for producing competent and technical professionals in the field of agriculture, Nepal Polytechnic Institute (NPI) under the Council of Technical Education and Vocational Training (CTEVT) started a B.Sc. agriculture program at Bharatpur and Chitwan in 2011. Along with JT and JTA program, CTEVT has been also producing village animal health worker program to mobilize technical workforce in village level.

Presently, there are around 3500 agriculture graduates have been working in Nepal. Approximately, 250 agriculture graduates, 70 veterinarians, and 80 forestry graduates are producing throughout the country but 30 percent of them are believed to go abroad either to study or for employment (Pokhrel, 2013). The Ministry of Agriculture and Development (MOAD) has 378 extension offices nationwide and each office serves more than 11,000 farmers; one technician is responsible for an average of 1,500 farmers, whereas in developed countries this ratio is 1 technician/400 farmers (IRIN, 2013). 


\section{Theoretical Perspectives}

Agriculture education and rural dev elopement in Nepal can be the best foot forwarded from agriculture transformation and modernization theory. In this theory, Nobel laureate economist (in1979)Theodore William Schultz emphasized that key to agricultural transformation lies in introducing new plantation technology, better species, more effective power sources and cheaper fertilizers and so on, that is, emphasizing technological change in agriculture (Lekhi,2012). More than 3 billion lived in rural areas in 1997 and around $70 \%$ of world poor lived in rural areas. The fact compelled to realize on transformation of traditional agriculture in the rural areas. Shultz argued that peasants are poor but efficient, they can bring about productivity increases and improvements provided they are given access to modern technologies. According to the conception of this theory, Schultz has given more focus to following assumptions (Lekhi, 2012).

- Lack and availability of the capital is another reason and he, like Schultz, thinks that peasants are more effective in producing output per additional unit of capital input.

- Given the enormous productive potential of agriculture, he stresses that in poor countries, large agricultural sectors should allocate more resources to agriculture.

- He does not belittle the importance of industrial sector but he wants the removal of those biases which stand on the way of transfer of resources from rural to urban areas.

- He further recommends that manufacturing and other urban sectors should not be subsidized with massive resource transfer from rural to urban areas.

- Agriculture as a tool of employment-based strategy requires three elements.

- Accelerated output growth to raise the productivity of small farmers.
- Raising domestic demand for agriculture output

- Diversified and non-agriculture labor-intensive intensive rural development activities that directly or indirectly support and are supported by the farming community.

Owing to traditional subsistence agriculture system, state mechanism must realize the importance of these theoretical assumptions for agricultural transformation which is equally benefitted to foster commercial farming and rural development activities in rural areas throughout the country. Nepalese farmers can also become rational actors who would react to changes and apply transformative farming system, if they are given real opportunities related to agriculture inputs like; seeds of high value crops, fertilizer, irrigation facilities, price policy as well as intensification/diversification of productions.

In the 1950 s and $1960 \mathrm{~s}$, modernization theory also provided a conceptual structure for the analysis and explanation of modern farming system. Modernization theory suggested that the main problem and modifying agricultural practices would not be in the research process, which was largely controlled by people with modern values. The great difficulties lay in the dissemination process, in which social and cultural obstacles to the adoption of new techniques and products could be anticipated in rural population with traditional attitudes and conservative value. With the process of modernization, rural society in influenced by the modern ideas i.e. it follows the characteristics of modern society. Moreover; communication, transportation, education, media (Electric media and paper media), local leaders, development agent's geographical factors etc are the responsible in transfering new technology in rural society.

Agricultural modernization refers to the process of equipping agriculture with modern science, technology and production methods, improving agricultural laborers' cultural and technological qualities and transforming laggard traditional agriculture into modern agriculture which guarantees 
advanced productivity (Xu, 1993). Agricultural modernization is not only a transformation process form traditional agriculture to modern agriculture but a sum of policies and measures to facilitate it (Chunfa, 1998).

\section{Policy Perspectives}

Policy reforms and economic growth across the globe have been changing demand and supply fundamentals sufficiently to turn agriculture into a more market-driven sector which provides investment opportunities, particularly in developing countries (OECD/FAO, 2013). Nepal is still one of the poorest countries in the world with a GNP per capita of US\$ 490 (WB, 2012), in which more than 21 percent people still live below poverty line (NLSS, 2010). The government has identified the agricultural sector as a key area for the achievement of development goals.

In Nepal, agricultural development is widely acknowledged as a critical component in a strategy to boost livelihoods of the people mostly living in rural areas and is now seen as an important part of any development strategy. Realizing this fact, the Government of Nepal has accorded top priority to agricultural growth for the improvement of living standards since the inception of a planned economy in 1956 (Aryal, 1970). Several policies were formulated and implemented in order to boost this sector. Such as: Agriculture Perspective Plan (APP) (1995-2015), Implementation of APP Support Programme (2003-2008), National Agriculture Policy (2004), National Water Plan (2005), Forestry Master Plan, National Transport Master Plan, Agribusiness Promotion Policy (2006), Milk Development Policy (2007), Agriculture Biodiversity Policy (2007) and recently Agriculture Development Strategy.

APP was first long term vision to increase agricultural productivity that stresses priority inputs (irrigation. rural roads, fertilizer and agricultural technology) to achieve priority outputs (increased production of fruits, vegetables, livestock, forestry and promotion of agri-business). The APP was designed to promote about 5 percent annual agricultural growth in order to achieve poverty alleviation goals set by the Government. It has emphasized applying modern technology as a one of the major priority input in farming system of the country. Since many years there has been a surge of interest and debate in public forum about the need to increase public sector investment in agriculture, and policy reform for agricultural development in Nepal.

Recently, Government of Nepal has prepared Agriculture Development Strategy (ADS), a 20-year strategy paper for agriculture sector development jointly collaborating with technical assistance (TA) team, financial support mainly from ADB, cofinanced by IFAD and contributions by EU, FAO, SDC, and JICA (MOA,2012). ADS aimed to allocate significant budget in agriculture sectors, intended to implement various capacity building, rural infrastructure development and research and agriculture development projects in coming future (MOA, 2012).

\section{Rural Development Efforts}

Rural development in Nepal is a complex phenomenon involving an interaction of economic, social, political and cultural factors. However, achievements of rural development efforts in Nepal are not satisfactory because of unstable political situation, absence of people participation and poor mobilization of youth mobilization in agriculture and rural development sectors. Rural development in Nepal started since 1956 but its impacts are questionable. The goal of rural development is to reduce poverty, unemployment and inequality for social and economic transformation. Therefore, rural development has been one of the prioritizing principle components of Nepal's development plan.

During the First Plan (1956-60), Tribhuvan Village Development Program was implemented into three levels: (I) 6 Minimum levels nucleus development for infrastructure development; (II) 34 Middle level Dehat (village) development for basic social service horticulture, animal husbandry and modern 
commercial seed and fertilizer and (III) 12 Intensive level or village development for cottage industries scientific farming and soil survey). For this program, government allocated 45 million and $13.6 \%$ of total budget and benefited 2.25 million people in 3800 villages (ICIMOD, 1985, p. 2).

During the Fifth Plan (1975-80), Special Group Program, New District Plan mainly for twin objectives how maximum utilization of manpower and people oriented production, Small Area Development Program, Hill Area Development Program and Integrated Rural Development Program were implemented. This plan aimed to implement target group oriented development approach or active people participation in decision making and meeting the basic need of rural areas in the overall development programs of the districts (APRSC, 1981, p. 41).

During the Ninth Plan (1997-2002), Rural Infrastructure Development Program, Agricultural Road Program, Rural access Program, District Road Support Program, Poverty Alleviation Project, Remote and Specific Area Development Program, Periodic District Development Plan have been implemented for overall development of rural areas.

During the Tenth Plan (2002-2007), Local body Strengthen Program, Policy and Institutional Reform Programs, Financial Resource Management Program, Human Resource Development Program, Local Infrastructure Development Program, Social Mobilization and Self-employment Program, and Integrated Reproductive Health and Population Education Program have been implemented. The Tenth Plan set the following objectives for the sector: (i) reduce poverty by increasing production, productivity, and income from agriculture, and contribute to food and nutritional security; (ii) contribute to sustainable production and growth by adaptive research and development of technology to be used in agriculture, while protecting and using agro-biodiversity and balance in the environment by reducing pollution from the use of external inputs; and (iii) develop the internal market and promote export opportunities by promoting agro-based industries and enterprises with the participation of cooperatives and private sector.

During 13th Three year plan (2070-71 to 2072/73), government set prime goal as for reduce poverty into $18 \%$ and objective as for reduce economic and human poverty and transformation of daily life of rural people. The long term goal is shifting Nepal as a least developing country to developing country up to 2022. Vocational education and training opportunities and national youth policy began to emphasize. For regional balance, Karnali Development Commission and Far western development commission were established.

\section{Status of Agriculture Development}

Nepal is predominantly an agrarian economy. It is the main source of livelihood of the Nepalese people. In terms of numbers, out of the 5.4 million households, 3.8 million households or about $71 \%$ are farming households, according to the National Agriculture Census (NAC, 2011/12). The total agricultural land is about 2.5 million hectares; about $30 \%$ of which is irrigated (Pant, 2013). A recent rough estimate by WFP stated that the minimum amount of land required for HHs self-sufficiency is approximately 0.54 ha (OCHA, 2008). Departments of Agriculture and that of Livestock Services are the responsible institutions for extension services provision.

In all 75 districts of the country, District Agriculture Development Offices (DADOs) and District Livestock Services Offices (DLSOs) are respectively designated for agriculture and livestock extension services. But the number of Agriculture Service Centers (ASCs) are 378 throughout the country while in the livestock subsector, there are 999 Livestock Service (Sub-) Centers (LS(S) Cs) varying in number from one district to another (FAO,2010). Such a poor networking system of public responsible agriculture institutions and mobilizing limited agriculture graduates are possible problems in 
agriculture development in Nepal. Agriculture system is also characterized by traditional farming methods, small land holdings and high dependence on monsoon rains for irrigation. Most of the farming households are subsistence farmers who consume what they produce; only $13 \%$ of produce is sold in the market (The World Bank). Rice is the main cereal crop; others are wheat, corn, barley and millet.

According to the Food and Agriculture Organization (FAO), Nepal was among the top producers of lentils and ginger in 2012 (Kantipur News, Feb 12, 2014). It was ranked as the sixth largest producer of lentils and the third largest producer of ginger. Cardamom, lentils, tea and ginger are also the leading agricultural export items. Nepal's ranked 83 out of 107 countries, with overall score of 34.4. (A higher score indicates higher food security) (The Economist Intelligence Unit, 2013). However, Nepalese economy has undergone a gradual structural shift in the recent years. The share of service sector has increased gradually and reached nearly half of the GDP. Table No. 1: Annual Percentage Change of GDP

\begin{tabular}{cc}
\hline Year & Annual \% change in GDP \\
\hline $2002 / 03$ & 3.8 \\
$2003 / 04$ & 4.4 \\
$2004 / 05$ & 3.2 \\
$2005 / 06$ & 3.7 \\
$2006 / 07$ & 2.8 \\
$2007 / 08$ & 5.8 \\
$2008 / 09$ & 3.9 \\
$2009 / 10$ & 4.3 \\
$2010 / 11$ & 3.8 \\
$2011 / 12$ & 4.6 \\
\hline
\end{tabular}

(Economic Survey, 2011/12, Ministry of Finance, Government of Nepal)

The given table 1 highlights the information on GDP contribution of the agricultural sector in Nepalese economy. The figure states that there was highest share $(5.8 \%)$ in $2007 / 08$ and lowest share $(2.8 \%)$ in $2006 / 07$. However there is a $4.03 \%$ average GDP contribution of agriculture sector but there has to be done various corrective measures for transformation of agriculture sector.

Table No. 2: Scenarios of Food Insecurity

\begin{tabular}{|c|c|}
\hline Description & Situation \\
\hline $\begin{array}{l}\text { People need of immediate food } \\
\text { assistance }\end{array}$ & 2.5 million \\
\hline $\begin{array}{l}\text { Food insecure due to rising food } \\
\text { prices }\end{array}$ & 4.4 million \\
\hline $\begin{array}{l}\text { Average HHs income spent on } \\
\text { food }\end{array}$ & $78 \%$ \\
\hline $\begin{array}{l}\text { Food price increase in last } 12 \\
\text { months }\end{array}$ & $30-60 \%$ \\
\hline $\begin{array}{l}\text { Districts food-deficient in } 2007 \\
\text { (based on local production) }\end{array}$ & 42 ( out of 75) \\
\hline $\begin{array}{l}\text { Estimated (rough) minimum } \\
\text { amount of land needed for food } \\
\text { self-sufficiency for mountain, } \\
\text { hills and Terai }\end{array}$ & $\begin{array}{l}0.64 \mathrm{ha}, 0.55 \mathrm{ha} \text {, } \\
\text { and } 0.45 \mathrm{ha}\end{array}$ \\
\hline $\begin{array}{l}\text { Estimated number of } \mathrm{HHs} \text { with } \\
\text { less than } 0.5 \text { ha Mountains } \\
\text { (Hills/Terai) }\end{array}$ & $\begin{array}{l}47 \%(49.2 \% / \\
41.3 \%)\end{array}$ \\
\hline $\begin{array}{l}\text { Land owned by top } 5 \% \text { of } \\
\text { landowners }\end{array}$ & $37 \%$ \\
\hline Landless population & $24.4 \%$ \\
\hline
\end{tabular}

The given table 2 shows the information on food insecurity. Data indicated that 2.5 million people need immediate assistance because of insufficient land and production and 4.4 million people are trapping in food insecurity because of raising price in food grains. Approximately, 78 percent average household income is invested for fooding. Similarly, out of total population, there are more than 40 percent landless household in mountain, hill and terai region and 24.4 percent land less population.

\section{Conclusion}

Concept of rural development is overall development in general and agriculture development in particular. Therefore, agriculture education can be a means for producing skilled workforce and agriculture graduates in central to local level. Although two thirds of people derive their livelihood and employment opportunity from agriculture sector but it is still marred by several 
problems. The dependence on traditional farming methods, unskilled farmers, poor mechanism of agriculture service delivery system, lack of storage facilities and access to markets and minimal agriculture graduates in rural areas are the major ones. No doubt, agriculture transformation and modernization process would raise productivity and output for addressing the food security problem in Nepal. But in Nepalese context it is still necessary to pursue higher emphasize in agriculture education program and agriculture service delivery mechanism by public and private sectors.

Agriculture education programs currently operating in Nepal can be classified in two different ways: a) Universities, which offer degree-granting programs in agriculture and b) Technical Schools and Polytechnics, offering a mix of short and long-term training programs in agriculture and related fields. But still government has to be given prime concern for providing agriculture educational opportunities to students and farmers in local level. Because of poor vision on human resource management most of the graduates are working in abroad. Presently, there are around 3500 agriculture graduates have been working in Nepal. The Ministry of Agriculture and Development (MOAD) has 378 extension offices nationwide and each office serves more than 11,000 farmers; one technician is responsible for an average of 1,500 farmers. Various policies and strategies are implemented now to then for agriculture development but agriculture education program are still in urban centric that must diffuse into remote rural areas too. Transforming rural livelihood and reduction of poverty was/is prime goal of rural development efforts which has given higher emphasize for agriculture development. Here is why, rural development has been one of the prioritizing principle components of Nepal's development plan since 1956 to till this moment.

Presently, 83 percent of total population $(26,494,504)$ is still living in rural areas whose primary occupation is agriculture. However, there is a $4.03 \%$ average GDP contribution by agriculture sector but Nepalese economy has undergone a gradual structural shift in the recent years. Still 2.5 million people need immediate assistance because of insufficient land and production and 4.4 million people are trapping in food insecurity because of raising price in food grains. To overcome food insecurity interventions have to be focused on food security and policy, agriculture education programming and implementation

But because of growing trend of specific and commercial farming system, Nepal has been ranked as the sixth largest producer of lentils and the third largest producers of ginger. Cardamom, lentils, tea and ginger are also the leading agricultural export items. Nepal is still one of the poorest countries in the world with a GNP per capita of US\$ 490 (WB, 2012), in which more than 21 percent people still live below poverty line (NLSS, 2010). For shifting Nepal from least developing country to developing country it is necessary to provide agriculture educational opportunities to majority of students in rural areas and in/formal training opportunities to farmers. Agriculture graduates must motivate and encourage toward working with farmers in the communities. Rural development without productive and transformative agriculture education system is almost impossible to commercialization of agriculture, food security, creating opportunities and overall development of rural areas of the country.

\section{References}

Adison, T. (2005). Agricultural development for peace.UNU WIDER Research Paper No. 2995/07. United Nations University, Helsinki, Finland.

APROSC (1981). Integreted rural Development : Profile, Inventory of Progrtammmes, Institutions and Bibilography. Country Report-nepal Agricultural Projects Services Centers (APROSC), Kathmandu.

Aryal, K. R. (1970). Education for the development of Nepal. Kathmandu: Shanti Prakashan.

CBS (2068). National Census of Agricultural Raw 
Statistical Estimate, Central Statistics Department, Thapathali, Kathmandu, Nepal.

Chunfa. W. (1998). Agricultural Modernization of Western Countries in Perspective. Shanghai Far East Publishers.

Food and Agriculture Organization (FAO) (2010). Agricultural Extension Services Delivery System in Nepal. Food and Agriculture Organization of the United Nations. UN Complex, Pulchowk, Nepal.

ICIMOD (1985). Integreted Rural Development in Nepal-A review: Internation center for integrated mountain development (ICIMOD). ICIMOD occasional paper 2, Kathmandu.

IRIN, (2013). Analysis: The trouble with Nepal's agriculture. Published on Jan 23rd, 2013. Retrieved from http://www.irinnews.org/ report/97321/analysis-the-trouble-with-nepal-s agriculture.

Kantipur newsathttp://www.ekantipur.com/ 2014/03/04/

Lekhi, R. K. (2008). The economics of development and planning (11th ed.). New Delhi: Kalyani Pubkishers

Ministry of Agriculture (2014). Twenty Years Agriculture Development Strategy (2014-34).

National Agriculture Census (NAC), 2011/12

National Planning Commission (2002). Tenth five year plan (2002-2007) Nepal Annual Household Survey (AHS) 2012/13 NPC (1995). Nepal Agricultural Perspective Plan, Kathmandu, Nepal.

NPC (2007). Interim Plan, (2007-2010). Kathmandu: Nepal Government Singha Darbar.
OCHA, 2008. Nepal Needs Analysis Framework Key Findings September 2008. United Nations Office for the Coordination of Humanitarian Affairs (UNOCHA). Kathmandu

OECD-FAO (2013). Agricultural outlook 2013 2022. Corrigenda OECD Publicatiopn.

Pant, B. (2013). Role of Inputs in Agriculture Transformation in Nepal, November 2013

Pieterse, J. N. (2001). Development Theory, Constructions and Reconstructions. Delhi: Vistaar Publication

Pokhrel, D. (2013). 'Brain Drain' of agriculture scientists (Nepali). Karobar Daily. March 28th, 2013. http://tinyurl.com/nly7u95

Singh, K. (1999). Rural Development, Principle, Policies and Management (2nd edition). New Delhi: Sage Publication.

Central Bureau of Statistics (CBS) athttp://cbs.gov.np http://cbs.gov.np/wp-content/uploads/2014/04/ Annual\%20GDP\%202013_14.pdf

Economist Intelligence Unit, 2014 Food Security Index at http://foodsecurityindex.eiu.com/ Country/Details \#Nepaland

Xu, G. (1993). Historical Experience in Agricultural Modernization and Its Enlightenment on China. Research Report of China Social Science Academy. 